\title{
Development of a novel in vitro 3D intestinal model for permeability evaluations
}

DOI:

10.1080/09637486.2019.1700940

\section{Document Version}

Accepted author manuscript

Link to publication record in Manchester Research Explorer

\section{Citation for published version (APA):}

Zhang, J., Penny, J., \& Lu, J. R. (2020). Development of a novel in vitro 3D intestinal model for permeability evaluations. International Journal of Food Sciences and Nutrition. https://doi.org/10.1080/09637486.2019.1700940

\section{Published in:}

International Journal of Food Sciences and Nutrition

\section{Citing this paper}

Please note that where the full-text provided on Manchester Research Explorer is the Author Accepted Manuscript or Proof version this may differ from the final Published version. If citing, it is advised that you check and use the publisher's definitive version.

\section{General rights}

Copyright and moral rights for the publications made accessible in the Research Explorer are retained by the authors and/or other copyright owners and it is a condition of accessing publications that users recognise and abide by the legal requirements associated with these rights.

\section{Takedown policy}

If you believe that this document breaches copyright please refer to the University of Manchester's Takedown Procedures [http://man.ac.uk/04Y6Bo] or contact uml.scholarlycommunications@manchester.ac.uk providing relevant details, so we can investigate your claim.

\section{OPEN ACCESS}




\section{Development of a novel in vitro 3D intestinal model for permeability}

\section{evaluations}

Jing Zhang ${ }^{\dagger}$, Jeffrey Penny ${ }^{\ddagger}$, Jian R Lu ${ }^{* \dagger}$

'Biological Physics Laboratory, School of Physics and Astronomy, Faculty of Sciences and Engineering, University of Manchester, Schuster Building, Manchester M13 9PL, UK

\#ivision of Pharmacy and Optometry, School of Health Sciences, Faculty of Biology,

Medicine and Health, University of Manchester, Stopford Building, Manchester M13 9PL, $U K$

Correspondence: Jian R Lu, Biological Physics Laboratory, School of Physics and Astronomy, Faculty of Sciences and Engineering, University of Manchester, Schuster Building, Manchester M13 9PL, UK. Tel: +44 161200 3926. Email: j.lu@manchester.ac.uk 


\title{
Development of a novel in vitro 3D intestinal model for permeability
}

\section{evaluations}

\begin{abstract}
In this work, a new three-dimensional (3D) in vitro cell model was described, which was comprised of an epithelium, a subepithelial fibroblast network and an extracellular matrix, thereby more closely mimicking the morphology of the small intestine. Transmission electron microscopy studies clearly revealed the complex structure of the new in vitro model. In a comparative study of drug absorption in the 3D model and a conventional Caco-2 monoculture cell model, the 3D model provided more physiological observations of transepithelial electrical resistance and alkaline phosphatase activity. The activities of two major intestinal xenobiotic efflux transporters, namely ABCB1 (P-glycoprotein, P-gp) and ABCG2 (Breast Cancer Resistance Protein, BCRP) were also studied, with the decreased ABCB1 activity and increased ABCG2 activity observed in the 3D model closer to the physiological characteristics of the human small intestine. A better correlation between drug permeability and human drug absorption was also observed from the 3D model, consistent with the better modelling of human intestine in structure and physiology.
\end{abstract}

Keywords: Caco-2, 3D model, TEER, drug transporter, drug permeability 


\section{Introduction}

The small intestine is a primary interface with the external environment and is the main site of absorption of nutrients. Furthermore, the small intestine is exposed to numerous noxious food-derived heterocyclic aromatic amines, including benzo[a]pyrene and 2-amino-1-methyl6-phenylimidazo[4,5]pyrine found in many cooked foods, with potential to cause cancer (Felton et al. 2000; Knize and Felton 2005). The small intestine also plays an important role in limiting exposure to such noxious xenobiotics, and polyspecific efflux transporters actively extrude xenobiotics out of intestinal epithelial absorptive cells. The ATP-Binding Cassette (ABC) transporters $\mathrm{ABCB} 1$ and $\mathrm{ABCG} 2$ are expressed in human small intestine (Estudante et al. 2013) and the detoxifying role of $\mathrm{ABCB} 1$ has been reported in studies showing ABCB1mediated transport of benzo[a]pyrene (Penny and Campbell 1994). The small intestine is also crucial for the efficient absorption of many therapeutic drugs, and a plethora of drugs are substrates of ABC transporters (Schinkel and Jonker 2012). Whilst some research and development merits experiments involving animals and humans, the global consensus has now been directed by the principle of replacement, reduction and refinement (the so-called 3Rs) (Flecknell 2002). Therefore, innovative development of in vitro models that can better mimic the small intestine is crucial in order to gain a better understanding of both nutrient absorption and absorption of therapeutic drugs, particularly those that are structurally based on nutrients. In general, in vitro cell models are more accurate than in silico models at predicting absorption due to their biological and physiological characteristics. Furthermore, although they are less complex than animal models, and their use provides valuable experimental data with fewer ethical concerns than animal models. Thus, it is feasible that an in vitro cell model that can better simulate the small intestine than existing ones will likely contribute to both healthcare and pharmacological research. 
The traditional Caco-2 cell model is derived from a human colon adenocarcinoma. Despite its origin, the well-differentiated Caco-2 cell mono-cultures bear significant morphological and biochemical resemblance to human small intestinal epithelial cells. Therefore, Caco-2 cell mono-cultures are widely used as an in vitro model of the human small intestine (Stockdale et al. 2019; Hidalgo, Raub, and Borchardt 1989a). In spite of its successful use in research, the Caco-2 cell model possesses several limitations. Firstly, there is a lack of cell heterogeneity and physiological structure since mono-cultures consist of only a single cell layer of epithelial absorptive cells with no underlying cellular and matrix structure. Thus, its structural over-simplification limits the accuracy of simulating the true environment of the human intestine. Secondly, the Caco-2 cell mono-culture may possess intercellular tight junctions that are more restrictive than those present in human small intestinal epithelium (Antunes et al. 2013; Artursson, Ungell, and Löfroth 1993). Since some hydrophilic compounds are absorbed through paracellular passive diffusion via the tight junctions, the Caco-2 cell model may not offer reliable information about compounds absorbed via the paracellular pathway. Thirdly, there are discrepancies between the Caco- 2 cell model and the human small intestinal epithelium in the expression levels and distribution of some metabolizing enzymes and transport proteins (DiMarco et al. 2017a). These limitations could potentially be resolved by modifying the complexity of existing the Caco-2 cell mono-culture model.

The in vivo intestinal epithelium is complex and consists of different epithelial cell types including mucus-producing goblet cells, immune cells and fibroblast cells, which all influence the epithelial barrier function. Some co-culture models of Caco-2 cells with mucussecreting HT29-MTX cells, or macrophages, have been established to modify the conventional Caco-2 cell model (Leonard, Collnot et al. 2010, Pan, Han et al. 2015), but most models are 2D cell cultures which do not account for underlying tissue architecture or 
interaction between epithelium and stroma, which is observed within the tissue microenvironment (Li et al. 2013).

In the human small intestine, subepithelial fibroblasts are the main cell type in intestinal stroma (Owens and Simmons 2013), and the subepithelial fibroblast network acts as a skeleton for the villi, ensuring provision of the mechanical structure, which acts as a barrier to foreign substances (Powell et al. 1999a, 1999b; Schweinlin et al. 2016). The subepithelial fibroblasts also regulate epithelial cell functions such as proliferation, migration, transepithelial resistance, and secretory responses (K. Furuya, Sokabe, and Furuya 2005; S. Furuya et al. 2005; Drygiannakis et al. 2013). Furthermore, it is reported that the extracellular matrix (ECM) proteins can promote the differentiation of Caco-2 cells (Basson et al. 1996). Therefore, the complexity of the traditional Caco- 2 cell model could be modified to better represent the human intestine by introducing subepithelial fibroblast cells and an ECM.

In this study we introduced $3 \mathrm{~T} 3$ cells (mouse embryonic fibroblasts) as subepithelial fibroblasts and type I collagen as ECM. By co-culturing Caco-2 cells with 3T3 cells suspended in the collagen layer, we fabricated an innovative three-dimensional (3D) intestinal cell model containing both an epithelial layer and subepithelial fibroblast network. This modified cell model can better simulate the in vivo human small intestinal mucosa and provide a more accurate and efficient system for the study of absorption characteristics within the drug development process.

\section{Experimental Section}

\section{Cell maintenance}

Human colon adenocarcinoma cells (Caco-2, passage 52-62) were cultured in medium composed of Dulbecco's modified Eagle's medium (DMEM) high glucose $(4500 \mathrm{mg} / \mathrm{L}$ glucose) with L-glutamine (Sigma Aldrich, cat.no. D6429), $10 \%$ (v/v) foetal bovine serum 
(FBS), $1 \%(\mathrm{w} / \mathrm{v})$ non-essential amino acids $(100 \mathrm{x})$ and $1 \%(\mathrm{w} / \mathrm{v})$ penicillin $5000 \mathrm{units} / \mathrm{mL}-$ streptomycin $5 \mathrm{mg} / \mathrm{mL}$. Mouse embryonic fibroblast cells (NIH 3T3) were grown in complete growth medium containing DMEM, $10 \%(\mathrm{v} / \mathrm{v})$ FBS, $1 \%$ penicillin-streptomycin and $1 \%$ ampicillin. Cells were maintained at $37{ }^{\circ} \mathrm{C}$ in a humidified atmosphere of $95 \%$ air and $5 \%$ $\mathrm{CO}_{2}$. They were routinely sub-cultured at $80-90 \%$ confluence. Culture medium was replaced on alternate days.

\section{Construction of 3D intestinal cell model}

$\mathrm{NIH} 3 \mathrm{~T} 3$ cells were suspended in a $1.5 \mathrm{mg} / \mathrm{ml}$ type I rat tail collagen solution (First Link Ltd), at a final cell concentration of $2 \times 10^{5}$ cells $/ \mathrm{ml}$. The suspension was pipetted into 12 -well Transwell inserts (Corning Transwell Clear, diameter: $12 \mathrm{~mm}$, pore size: $0.4 \mu \mathrm{m}$ ). After gelation of collagen at $37{ }^{\circ} \mathrm{C}$ for $30 \mathrm{~min}, 500 \mu \mathrm{l}$ of Caco- 2 cell suspension $\left(4 \times 10^{5}\right.$ cells $\left./ \mathrm{ml}\right)$ was added onto the surface of the collagen gel. Co-cultures were then incubated at $37{ }^{\circ} \mathrm{C}$ in Caco-2 cell growth medium for up to 21 days. In addition, for the sake of comparison, Caco2 cell mono-culture models lacking 3T3 cells were also established.

\section{Measurement of transepithelial electrical resistance (TEER)}

TEER is widely used to assess the integrity and permeability of cell-based models (Srinivasan et al. 2015; Rhayat et al. 2019). The TEER of both Caco-2 cell mono-culture and Caco-2 / 3 T3 co-culture cell models housed in 12-well Transwell inserts was measured using an EVOM (World Precision Instruments). A blank Transwell insert with no cells served as a blank control for the mono-culture model whilst a Transwell insert with $3 \mathrm{~T} 3$ cells in the collagen layer served as a blank control for the co-culture model. TEER values $\left(\Omega \cdot \mathrm{cm}^{2}\right)$ from both 3D and mono-culture cell models were calculated using equation (1):

$$
\operatorname{TEER}=\left(R-R_{\text {blank }}\right) A
$$


where $R$ is the resistance measured across the cell layer(s), $R_{\text {blank }}$ is the resistance of a blank Transwell insert lacking cells for the mono-culture model or a Transwell insert with 3T3 cells in the collagen layer for the co-culture model, and $A$ is the surface area of a Transwell insert $\left(1.12 \mathrm{~cm}^{2}\right)$.

\section{Measurement of Lucifer yellow apparent permeability}

Lucifer yellow, a fluorescent probe which crosses cell layers via the paracellular pathway, is commonly used to evaluate the integrity (i.e. restrictive nature) of in vitro cell model systems (Zhang et al. 2004; Faralli et al. 2019). Caco-2 mono-cultures, Caco-2 / 3T3 3D co-culture models and 3T3 cells in collagen were maintained in 12-well Transwell inserts and incubated at $37{ }^{\circ} \mathrm{C}$ for 21 days. The culture medium was then removed and both apical and basolateral compartments were washed twice with Hanks' balanced salt solution (HBSS). HBSS (500 $\mu 1)$ containing Lucifer yellow $(20 \mu \mathrm{g} / \mathrm{ml})$ was added to the apical chamber and HBSS $(1500 \mu \mathrm{l})$ was added to the basolateral chamber and samples, $100 \mu \mathrm{l}$, were collected from the basolateral chamber every $30 \mathrm{~min}$, for up to $120 \mathrm{~min}$. In order to maintain the volume in the basolateral chamber, after each sample collection, $100 \mu$ fresh HBSS was added into the chamber. The quantity of Lucifer yellow in each sample was determined by measuring fluorescence at an excitation wavelength of $450 \mathrm{~nm}$ and an emission wavelength of $520 \mathrm{~nm}$ using a Tecan Safire multiplate reader. The apical to basal apparent permeability coefficient $\left(\mathrm{P}_{\mathrm{app}}, \mathrm{cm} / \mathrm{s}\right)$ of Lucifer yellow was calculated using equation 2 :

$$
P_{a p p}=A C_{o} \frac{d Q}{d t}
$$

where $d Q / d t$ is the amount of Lucifer yellow transported within a given time period $(\mu \mathrm{g} / \mathrm{s}), C_{0}$ is the initial Lucifer yellow concentration $(\mu \mathrm{g} / \mathrm{ml})$ in the apical chamber, and $A$ is the surface area $\left(\mathrm{cm}^{2}\right)$ of the insert membrane $\left(1.12 \mathrm{~cm}^{2}\right)$. A Transwell insert lacking cells served as blank. 


\section{Visualization of viable cells of the 3D model}

To visualize the viability of cells, $3 \mathrm{~T} 3$ cells in collagen grown in 24-well plates were treated with $1 \mu \mathrm{M}$ Calcein-AM for $30 \mathrm{~min}$, and Caco- 2 cells in suspension were treated with $5 \mu \mathrm{M}$ CellTracker Red for 30 min prior to co-culturing in 24 -well plates. Images of viable cells were obtained with a Nikon Eclipse TE2000-U fluorescent microscope, and cross-sectional analysis of the Caco-2 /3T3 3D model was carried out using a Zeiss LSM510 confocal laser scanning microscope (CLSM) with an excitation wavelength of $490 \mathrm{~nm}$ and an emission wavelength of $520 \mathrm{~nm}$ for Calcein-AM and $577 \mathrm{~nm}$ and $602 \mathrm{~nm}$ for CellTracker Red.

\section{Transmission electron microscopy (TEM)}

After culturing for 21 days, both Caco-2 mono-culture and Caco-2 / 3T3 co-culture cell models were prepared for TEM analysis. Transwell insert membranes were washed twice in PBS and fixed with $4 \%(\mathrm{v} / \mathrm{v})$ formaldehyde and $2.5 \%(\mathrm{v} / \mathrm{v})$ glutaraldehyde in $0.1 \mathrm{M}$ Hepes buffer ( $\mathrm{pH}$ 7.2). Membranes were then treated with $1 \%(\mathrm{w} / \mathrm{v})$ osmium tetroxide and $1.5 \%$ (w/v) potassium ferrocyanide in $0.1 \mathrm{M}$ cacodylate buffer $(\mathrm{pH} 7.2)$ for $1 \mathrm{~h}$, post fixed in $1 \%$ $(\mathrm{w} / \mathrm{v})$ tannic acid in $0.1 \mathrm{M}$ cacodylate buffer for $1 \mathrm{~h}$ and finally washed in $1 \%(\mathrm{w} / \mathrm{v})$ uranyl acetate in water for $1 \mathrm{~h}$. The samples were dehydrated in 50, 75, 96, 100\% ethanol and embedded in TAAB 812 resin which was polymerized for $24 \mathrm{~h}$ at $60{ }^{\circ} \mathrm{C}$. Sections were cut with a Reichert Ultracut ultramicrotome and then placed in a FEI Tecnai 12 Biotwin microscope at $100 \mathrm{kV}$ accelerating voltage. Images were obtained with a GatanOrius SC1000 CCD camera.

\section{Immunostaining of tight junction protein}


The level of expression of the tight junction protein zonula occludens-1 (ZO-1) in both Caco2 mono-culture and Caco-2 / 3T3 co-culture models was measured by immunofluorescence (Li et al. 2013). Cell models grown in 12-well Transwell inserts were fixed in $4 \%(\mathrm{v} / \mathrm{v})$ paraformaldehyde in $0.1 \mathrm{mmol} / 1 \mathrm{PBS}(\mathrm{pH} \mathrm{7.4)}$ and washed with PBS. Cells were then treated with a $0.3 \%(\mathrm{v} / \mathrm{v})$ Triton-X-100 solution (Sigma-Aldrich) at room temperature for $1 \mathrm{~h}$. After blocking with $1 \%(\mathrm{w} / \mathrm{v})$ bovine serum albumin (Sigma-Aldrich), samples were incubated with mouse anti-human ZO-1 (1:100; BD Biosciences) at $4{ }^{\circ} \mathrm{C}$ overnight, washed with PBS to remove non-specifically bound primary antibody, and incubated with FITC-conjugated goat anti-mouse IgG (Sigma) for $2 \mathrm{~h}$. Cell nuclei were subsequently counterstained with propidium iodide (PI, $5 \mathrm{mg} / \mathrm{mL}$; Invitrogen). Representative fluorescent images were obtained using a Nikon Eclipse TE2000-U fluorescent microscope. The expression level of ZO-1 protein was quantified as the quotient of FITC fluorescence intensity over nucleiassociated PI fluorescence intensity using ImageJ software.

\section{Measurement of alkaline phosphatase activity}

Alkaline phosphatase activity in both Caco-2 mono-culture and Caco-2 / 3 T3 co-culture cell models was determined following the method described by Sobue et al (Sobue et al. 1999). Both models were maintained in 96-well plates for 21 days, and alkaline phosphatase activity measured on day 7, 9, 14 and 21. Cell models were washed with PBS, and incubated in 275 $\mu 1$ of $10 \mathrm{mM}$ p-nitrophenyl phosphate in $0.7 \mathrm{M}$ 2-amino-2-methyl-1-propanol $\mathrm{pH} 10.2$ and 1 $\mathrm{mM} \mathrm{MgCl} 2$ for $10 \mathrm{~min}$ at $37{ }^{\circ} \mathrm{C}, 5 \% \mathrm{CO}_{2}$ and $1 \mathrm{~N} \mathrm{NaOH}, 55 \mu$, was added to terminate the reaction. The amount of $p$-nitrophenol produced was determined spectrophotometrically at $410 \mathrm{~nm}$ using a molar extinction coefficient of $17,000 \mathrm{M}^{-1} \cdot \mathrm{cm}^{-1}$. Enzyme activity is expressed as specific enzyme activity $\left(\mathrm{nmol} \cdot \mathrm{min}^{-1} \cdot \mathrm{mg}\right.$ protein $\left.{ }^{-1}\right)$. The protein content was determined by the method of Bradford (Bradford 1976), and bovine serum albumin served as the standard. 


\section{Measurement of ABCB1 and ABCG2 functional activity}

In order to assess the functional activity of $\mathrm{ABCB} 1$, intracellular of calcein was determined in both Caco-2 mono-culture and Caco-2 / 3T3 co-culture models (Korjamo et al. 2005; Al-Ali et al. 2018). Both models were prepared in 24-well plates. They were washed twice with warm PBS and pre-incubated with either phenol red-free DMEM or phenol red-free DMEM containing verapamil $(200 \mu \mathrm{M})$ at $37{ }^{\circ} \mathrm{C}$ for $30 \mathrm{~min}$. Then, appropriate medium containing calcein-AM $(1 \mu \mathrm{M})$ was added to each well and plates incubated for a further $30 \mathrm{~min}$ at 37 ${ }^{\circ} \mathrm{C}$. The calcein-AM containing media were then replaced by ice-cold PBS and the intracellular fluorescence measured using a Tecan Safire multiplate reader with excitation and emission wavelengths of 484 and $530 \mathrm{~nm}$ respectively.

The function of ABCG2 (Breast Cancer Resistance Protein, BCRP) was assessed by measuring the intracellular accumulation of the fluorescent substrate Hoechst 33342. KO143 was used as a selective ABCG2 inhibitor (Allen et al. 2002; Isshiki, Umezawa, and Tamura 2011; Wu et al. 2018). Caco-2 mono-culture and Caco-2 / 3T3 co-culture models were incubated at $37^{\circ} \mathrm{C}$ for 30 min with either phenol red-free DMEM or phenol red-free DMEM containing KO143 $(10 \mu \mathrm{M})$. Cell models were then incubated with appropriate medium containing $5 \mu \mathrm{M}$ Hoechst 33342 for $30 \mathrm{~min}$. Intracellular fluorescence was measured with a Tecan Safire multiplate reader with excitation and emission wavelengths of $350 \mathrm{~nm}$ and 480 nm respectively.

\section{Drug permeability assay}

A series of drugs with reported low permeability (enalaprilat, lisinopril, and lucifer yellow) moderate permeability (atenolol, furosemide, and hydrochlorothiazide) and high permeability (antipyrine, propranolol, and ketoprofen) were used to investigate the corresponding apparent 
permeability $\left(\mathrm{P}_{\mathrm{app}}\right)$ in both Caco-2 mono-culture and Caco-2 / 3T3 co-culture models. Furthermore, drugs that are subjected to intestinal efflux transport, digoxin, verapamil and quinidine, were also used to evaluate transporter function in both models. The effect of compounds on cell viability was determined using the MTT assay, as described by Jariya Kowapradit et.al (Kowapradit et al. 2010).

Both models were incubated for 21 days in 12-well Transwell inserts. Models were washed twice with HBSS and pre-incubated with HBSS at $37{ }^{\circ} \mathrm{C}$ for $15 \mathrm{~min}$. The HBSS in the donor (apical) compartment was removed and replaced with HBSS containing drug at $100 \mu \mathrm{M}$. At 0, 30, 60, 90 and 120 min $100 \mu \mathrm{HBSS}$ was removed from the receiver (basolateral) compartment and $100 \mu \mathrm{l}$ HBSS was added in order to maintain a constant volume. The amount of compound in the samples was measured by HPLC (Agilent 1100 series, Agilent technology, Germany) using a Supelco C18 ODS $5 \mu \mathrm{m} 4.6 \times 150 \mathrm{~mm}$ column. The mobile phase varied with compound (antipyrine: $75 \%(\mathrm{v} / \mathrm{v})$ water and $25 \%(\mathrm{v} / \mathrm{v})$ acetonitrile, UV detector was set at $254 \mathrm{~nm}$; propranolol: $70 \%$ (v/v) water (to $\mathrm{pH} 3.0$ with $20 \mathrm{mM} \mathrm{KH}_{2} \mathrm{PO}_{4}$ ) and $30 \%(\mathrm{v} / \mathrm{v})$ acetonitrile, $294 \mathrm{~nm}$; ketoprofen: $60 \%(\mathrm{v} / \mathrm{v})$ water (to $\mathrm{pH} 3.0$ with $20 \mathrm{mM}$ $\mathrm{KH}_{2} \mathrm{PO}_{4}$ ) and $40 \%(\mathrm{v} / \mathrm{v})$ acetonitrile, $260 \mathrm{~nm}$; atenolol: $70(\mathrm{v} / \mathrm{v}) \%$ water (to $\mathrm{pH} 3.0$ with 20 $\left.\mathrm{mM} \mathrm{KH} \mathrm{PO}_{4}\right)$ and $30(\mathrm{v} / \mathrm{v}) \%$ acetonitrile, $225 \mathrm{~nm}$; furosemide: $60(\mathrm{v} / \mathrm{v}) \%$ water (to $\mathrm{pH} 4.0$ with formic acid) and 40 (v/v) \% acetonitrile, $230 \mathrm{~nm}$; hydrochlorothiazide: 70 (v/v) \% water and $30(\mathrm{v} / \mathrm{v}) \%$ acetonitrile, $270 \mathrm{~nm}$; enalaprilat: $60 \%(\mathrm{v} / \mathrm{v})$ water (to $\mathrm{pH} 3.0$ with $20 \mathrm{mM}$ $\mathrm{KH}_{2} \mathrm{PO}_{4}$ ) and $40 \%(\mathrm{v} / \mathrm{v})$ acetonitrile, $215 \mathrm{~nm}$; lisinopril: $82 \%(\mathrm{v} / \mathrm{v})$ water (to $\mathrm{pH} 3.0$ with 20 $\left.\mathrm{mM} \mathrm{KH} \mathrm{PO}_{4}\right)$ and $18 \%(\mathrm{v} / \mathrm{v})$ acetonitrile, $215 \mathrm{~nm}$; digoxin: $70 \%(\mathrm{v} / \mathrm{v})$ water and $30 \%(\mathrm{v} / \mathrm{v})$ acetonitrile, $220 \mathrm{~nm}$; verapamil: $60 \%$ (v/v) water (to $\mathrm{pH} 4.0$ with formic acid) and $40 \%$ (v/v) acetonitrile, 278nm; quinidine: $70 \%$ (v/v) water (to $\mathrm{pH} 4.0$ with formic acid) and $30 \%(\mathrm{v} / \mathrm{v}$ ) acetonitrile, $250 \mathrm{~nm}$ ) (Shen and Wanwimolruk 1991; Tajerzadeh and Hamidi 2001; Srikanth et al. 2012; Charde and Welankiwar 2014; Sultana et al. 2012; Bhagwate 2013; Srivastava 
and Ali 2014; Patil et al. 2012). The apparent permeability coefficient ( $\left.\mathrm{P}_{\text {app }}\right)$ of therapeutic drugs was calculated using equation (2), where $\mathrm{C}_{0}$, the initial concentration of the compound in the donor compartment was $100 \mu \mathrm{M}$. The $\mathrm{P}_{\text {app }}$ of the 12 model drugs was then compared to the corresponding fraction of the dose absorbed (Fa \%) in human studies and the data sets were fitted by logarithmic regression with correlation coefficient $\left(\mathrm{R}^{2}\right)$ calculated.

\section{Statistics}

Results were expressed as mean \pm standard deviation, and statistical analysis was by twosample Student's t-test assuming unequal variances. Differences were considered statistically significant when $p<0.05$.

\section{Results}

\section{Viability and structure of 3D model}

A Caco-2 / 3T3 3D co-culture model was developed as described in the Experimental Section. In this model both cell types retained significant levels of intracellular fluorescence, indicating that cells remained intact. Initially, the fluorescence-associated with Caco-2 cells was of a compact, circular nature, reflecting the morphology of the cells following plating on day 0 (Figure 1 B). Over time, i.e. day 4 and day 10, intracellular fluorescence became more widespread and diffuse, consistent with replication and spreading of Caco-2 cells across the gel surface (Figure 1 D, F). At day 0, classical fibroblast morphology was observed, with high intensity intracellular fluorescence (Figure $1 \mathrm{~A}$ ) and this classical intact morphology was observed throughout day 4 and day 10 (Figure $1 \mathrm{C}, \mathrm{E}$ ) of the culture period. Further imaging studies revealed a gradual reduction in fluorescence over time, which is widely observed in living cells. Cross sectional analysis of the Caco-2 / 3T3 3D model by confocal laser scanning microscopy revealed a complex 3D structure with a distinct upper layer of Caco-2 cells (red fluorescence) and underlying 3T3 fiboblasts (green fluorescence) associated with the gel matrix (

Figure 1, G). 


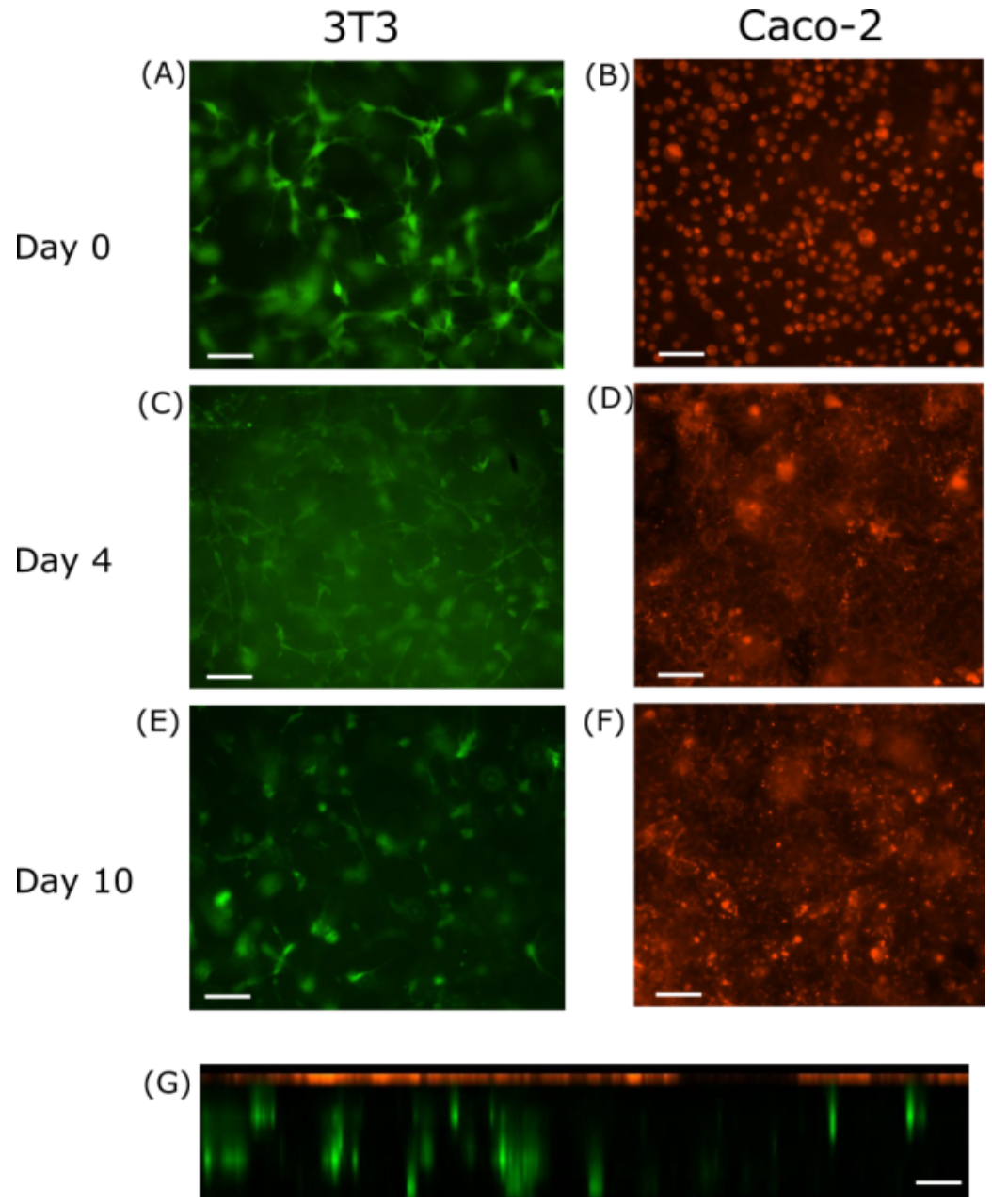

Figure 1 Fluorescence microscopic analyses of Caco-2 mono-culture and Caco-2 / 3T3 3D co-culture models. 3 T3 cells (A, C, E) were initially grown in collagen gel in 12-well Transwell inserts for 2 days, and were then treated with Calcein-AM for $30 \mathrm{~min}$. Caco-2 cells $(\mathrm{B}, \mathrm{D}, \mathrm{F})$ in suspension were treated with CellTracker Red for 30 min prior to seeding onto the surface of the $3 \mathrm{~T} 3$ gel culture. Fluorescent images (A-F) were obtained using a Nikon Eclipse TE2000-U fluorescence microscope and confocal images $(\mathrm{G})$ were obtained with a Zeiss LSM510 confocal laser scanning microscope (Caco-2 cells, red fluorescence; 3T3 cells, green fluorescence). Representative images from individual experiments are shown. Representative confocal image of the z-plane cross-section of the Caco-2 / $3 \mathrm{~T} 3$ co-culture model at day 10 indicating the surface Caco-2 cell layer (red fluorescence) and 3T3 cells embedded within the collagen matrix (green fluorescence). Scale bar $=100 \mu \mathrm{m}$.

\section{Transmission electron microscopy}


TEM was used to investigate the ultra-structural morphology of Caco-2 cells in both Caco-2 mono-culture and Caco-2 / 3 T3 co-culture models on Day 21. In the mono-culture cell model the Caco-2 cells were highly differentiated, possessing both microvilli and tight junction complexes (Figure 2 A, B). In the co-culture cell model, the Caco-2 cells successfully grew on top of the $3 \mathrm{~T} 3$ cell-impregnated gel surface and, as in the Caco-2 mono-culture model, became well-differentiated with microvilli and tight junctions clearly observable (Figure $2 \mathrm{C}$, D). These findings indicate that this co-culture cell model, comprising co-cultures of Caco-2 cells and $3 \mathrm{~T} 3$ cells, can therefore be employed to measure penetration of compounds of interest.
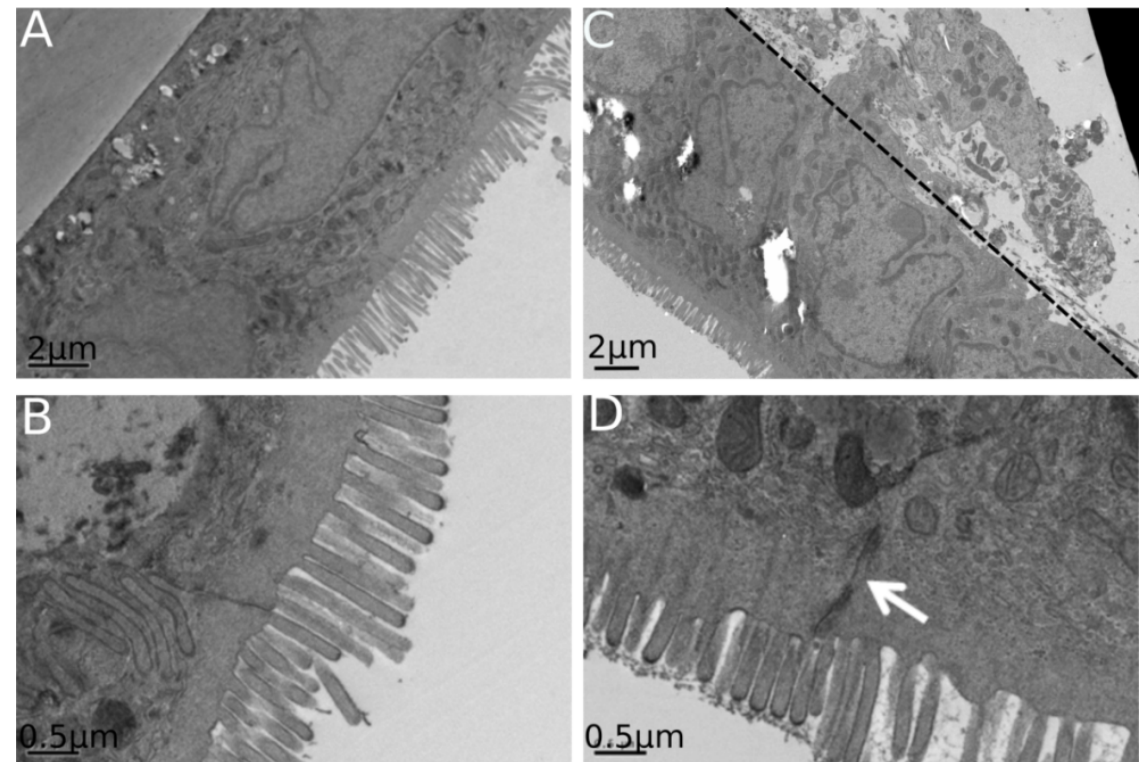

Figure 2 Transmission electron micrographs of Caco-2 mono-culture and Caco-2 / 3T3 3D co-culture models. Caco-2 cell mono-culture (A and B) and the Caco-2 / $3 \mathrm{~T} 3$ co-culture model (C and D) were grown for 21 days on 12-well Transwell polyester inserts. Panel A shows an intact Caco-2 cell monoculture adhered to the polyester membrane and $\mathrm{C}$ depicts an intact Caco-2 cell mono-culture growing on $3 \mathrm{~T} 3$ cells embedded within a collagen gel. The boundary region between the Caco- 2 cell monoculture and $3 \mathrm{~T} 3$ cells embedded within a collagen gel is indicated by the dotted line in C. Panels B and D demonstrate that Caco-2 cells were well differentiated in both Caco-2 mono-culture and Caco-2 / 3 T3 co-culture cell models, with obvious microvilli, and a tight junction is indicated with an arrow. 


\section{Alkaline phosphatase activity}

Differentiated Caco-2 cells express brush-border enzymes such as alkaline phosphatase, sucrase and aminopeptidase (Kenny and Maroux 1982; García-Rodríguez et al. 2018), among which alkaline phosphatase is well known as a marker of Caco-2 cell differentiation (Zucco et al. 2005; Hymery, Mounier, and Coton 2018). In this work, alkaline phosphatase specific activity in Caco-2 cells was measured with $p$-nitrophenyl phosphate ( $p$ NPP) as substrate, with activity being displayed in Figure 3, There was a temporal increase in alkaline phosphatase specific activity in both Caco-2 mono-culture and Caco-2 / 3T3 co-culture models, while activity in the co-culture model was consistently higher than in the mono-culture model, potentially suggesting a more physiologically-representative environment.

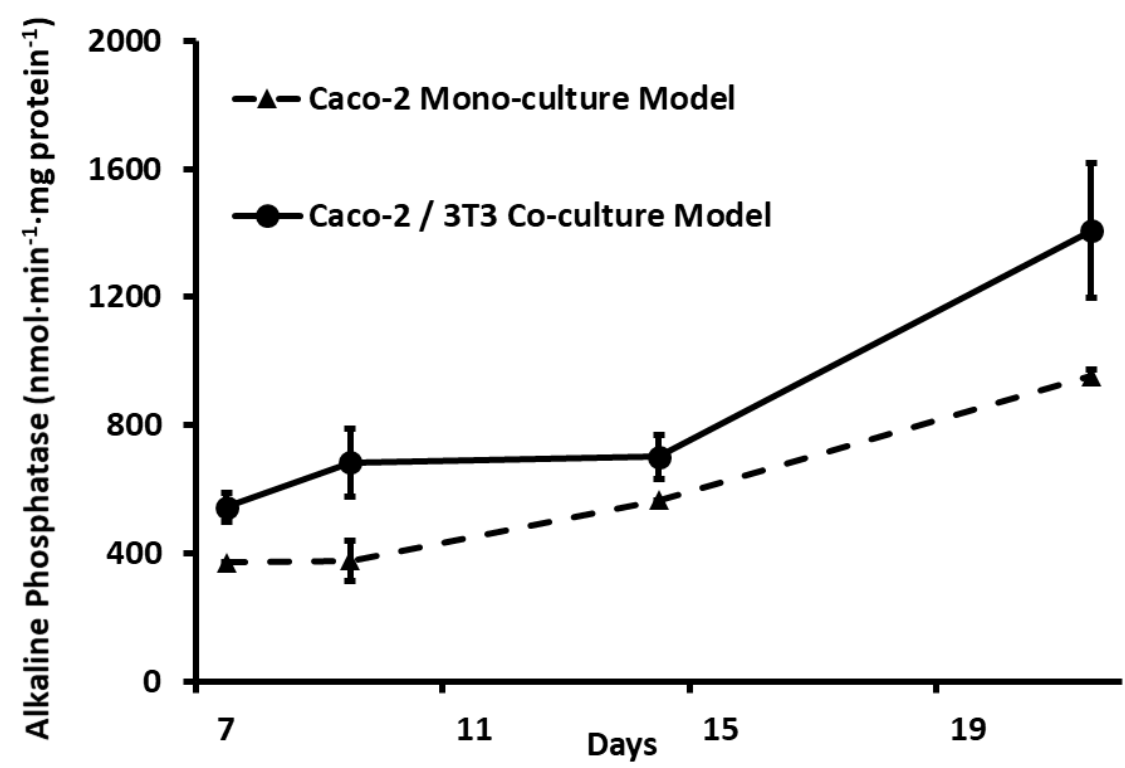

Figure 3 Alkaline phosphatase activities determined against time with $p$-nitrophenol as substrate. Data were recorded at day 7, 9, 14, 21 for both Caco-2 mono-culture and Caco-2 / 3T3 co-culture models. Data are the mean \pm SD from two experiments each containing 5 replicates. 


\section{Integrity of cell models}

The integrity and restrictive paracellular characteristics of Caco-2 cell layers are determined by the formation of tight junctions between adjacent cells. TEER measurements were taken to reveal how the integrity of the Caco-2 cell layer in the Caco-2 mono-culture and Caco-2 / 3T3 co-culture cell models developed over time.

The TEER values of both the Caco-2 mono-culture and the Caco-2 / 3T3 co-culture models generally increased steadily from day 3 to day 22 (Figure 4,A). The rate of TEER increase in the mono-culture model was much higher than that in co-culture model, whilst TEER values from the $3 \mathrm{~T} 3$ cell monoculture remained negligible and stable, indicating that, in the coculture model, the TEER is primarily determined by the upper Caco-2 cell mono-culture.

\section{Lucifer yellow permeability}

Both Caco-2 mono-culture and Caco-2 / 3 T3 co-culture models were cultured on 12-well Transwell inserts. The apparent permeability coefficient $\left(\mathrm{P}_{\text {app }}\right)$ of Lucifer yellow in each model was evaluated in the apical to basolateral (i.e. absorptive) direction, as shown in Figure 4 B. The average $P_{\text {app }}$ of Lucifer yellow in the mono-culture model was $(6.47 \pm 1.59)$ $\times 10^{-8} \mathrm{~cm} / \mathrm{s}$. In contrast, the average $\mathrm{P}_{\text {app }}$ in the co-culture model was $(1.84 \pm 0.20) \times 10^{-7} \mathrm{~cm} / \mathrm{s}$, more than 3 times higher than that of the mono-culture model. In empty Transwell inserts employed as blank, the average $\mathrm{P}_{\text {app }}$ was $(1.83 \pm 0.15) \times 10^{-5} \mathrm{~cm} / \mathrm{s}$, while in Transwell inserts with only collagen containing $3 \mathrm{~T} 3$ cells the average $\mathrm{P}_{\text {app }}$ was $(2.70 \pm 0.77) \times 10^{-6} \mathrm{~cm} / \mathrm{s}$. 

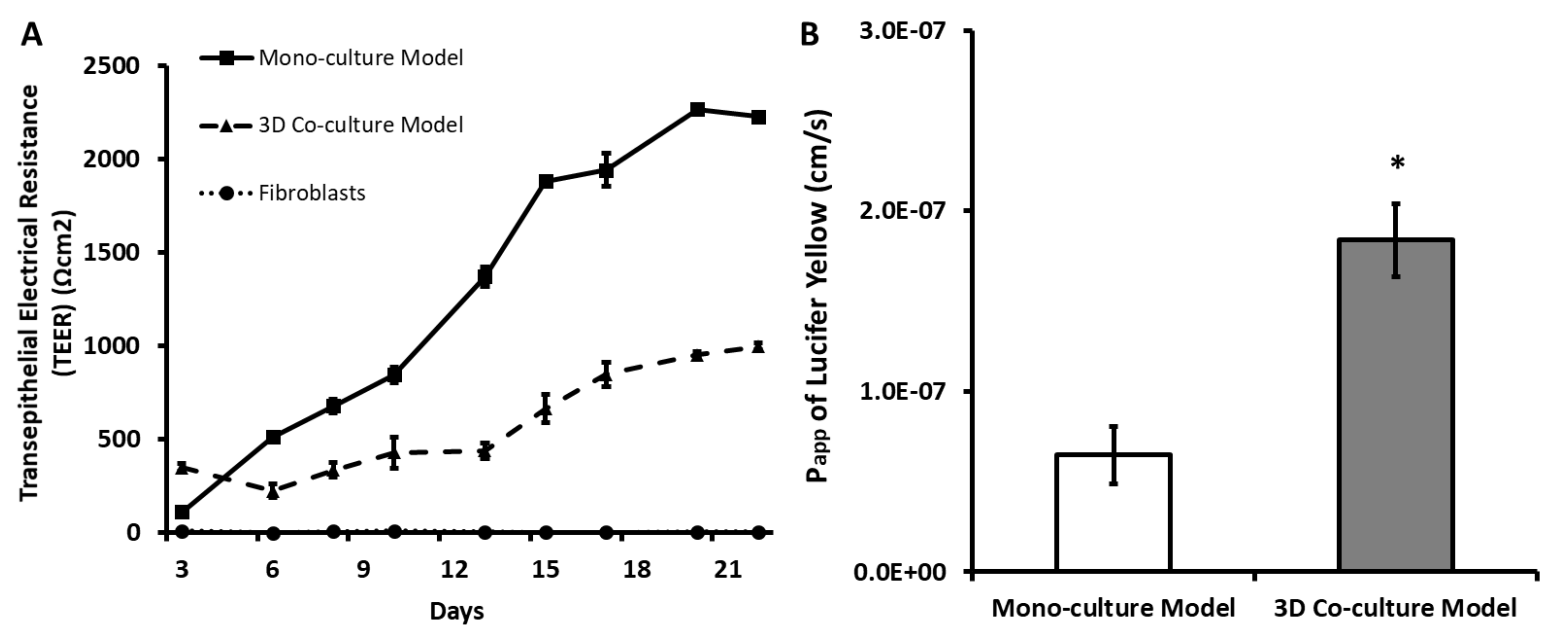

Figure 4 The integrity of Caco-2 mono-culture and Caco-2 / 3T3 3D co-culture cell models. (A) The TEER of Caco-2 mono-culture s and Caco-2 / 3T3 co-culture cell models maintained on 12-well Transwell inserts. Data were recorded from Day 3 to Day 22, with the TEER readings from blank Transwells serving as control for Caco-2 mono-culture s and TEER readings from $3 \mathrm{~T} 3$ cells growing in collagen serving as control for the co-culture model. (B) The apical to basolateral apparent permeability coefficient of Lucifer yellow in Caco-2 mono-culture and Caco-2 / 3T3 3D co-culture models. Results are expressed as mean \pm SD of 3 independent experiments with 3 replicates in each experiment, ${ }^{*} p<0.05$.

\section{Immunostaining of the tight junction protein $\mathrm{ZO}-1$}

The structural integrity of the intestinal epithelial barrier is mainly maintained by tight junctions (Ulluwishewa et al. 2011). ZO-1 is one of the most important structural proteins comprising the tight junction complexes, with its level of expression influencing the restrictive nature of tight junctions (Balda et al. 1992). The levels of ZO-1 in both Caco-2 mono-culture and Caco-2 / 3T3 3D co-culture cell models were assessed by immunofluorescence. The level of ZO-1 protein expression (i.e. green fluorescence) in the co-culture model, normalised to nuclei-associated propidium iodide fluorescence, (Figure $\mathbf{5}$ 
difference is consistent with the fact that Lucifer yellow $\mathrm{P}_{\mathrm{app}}$ in the 3D co-culture model was greater than in the Caco-2 mono-culture model, and with the findings that the TEER of the 3D co-culture model was less than was observed in the Caco-2 mono-culture model.

\section{Mono-culture Model}

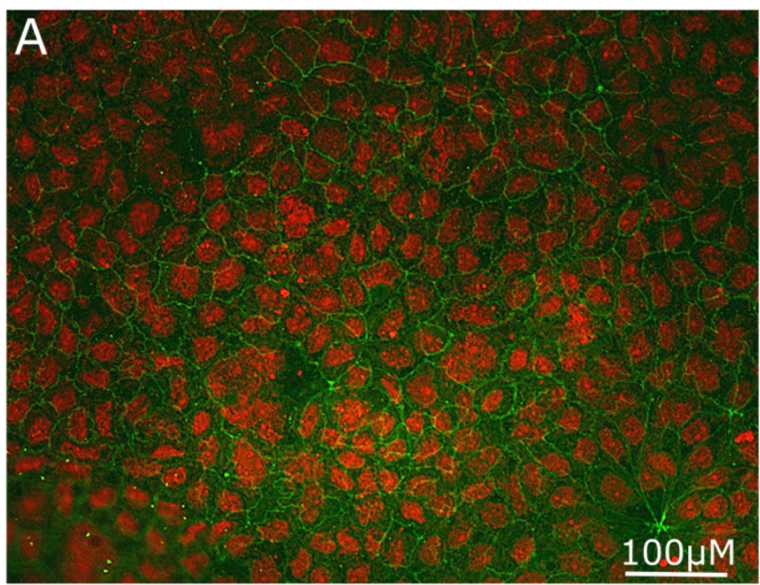

\section{D Co-culture Model}

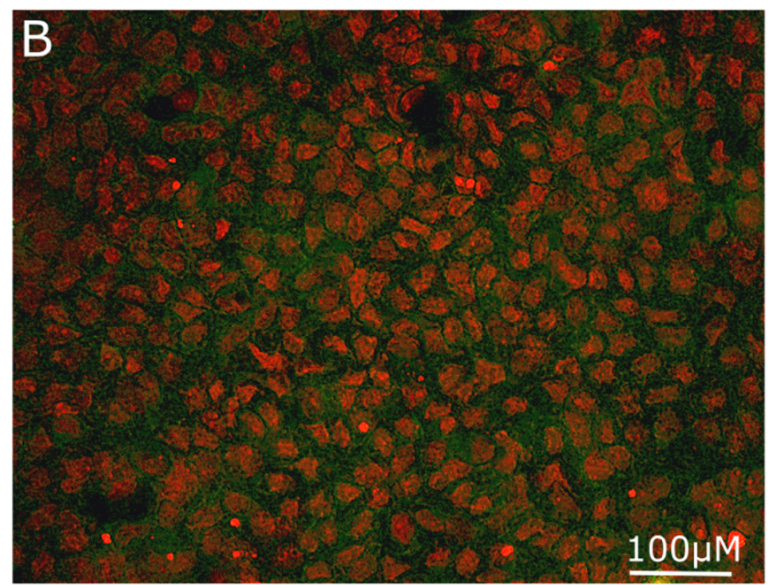

Figure 5 Immunostaining showed the expression of protein ZO-1 (green fluorescence) around the periphery of Caco-2 cells in the Caco-2 mono-culture model (A) and the Caco-2 / 3T3 3D co-culture model (B). A relative lower level of ZO-1 expression was observed in the Caco-2 / 3T3 3D co-culture model than in the Caco-2 mono-culture model, consistent with less restrictive tight junctions in the co-culture model. Cell nuclei were counterstained with propidium iodide (red fluorescence). Representative images from 3 independent experiments are shown.

\section{Activities of transport proteins}

Another shortcoming of the conventional Caco-2 mono-culture model is that the expression levels of transport proteins differ from those in human intestine (Le Ferrec et al. 2001). Efflux transporter proteins in the small intestine can impact on the absorption of dietary and environmental xenobiotics, as well as therapeutic drugs and may influence exposure to xenobiotics, pharmacokinetics, drug-drug interactions and drug safety (Murakami and Takano 2008). The ABCB1 (P-gp, MDR1), ABCG2 (BCRP), and ABCC2 (MRP2) efflux 
transporters are expressed in human small intestine (Estudante et al. 2013) whilst ABCB1 and ABCG2 are expressed in Caco-2 cells.

Verapamil-sensitive ABCB1 efflux activity was measured in both the Caco-2 mono-culture and Caco-2 / 3T3 3D co-culture models, Figure 6 A. Treatment with the ABCB1 inhibitor verapamil $(200 \mu \mathrm{M})$, resulted in a significant increase in the normalised intracellular calcein fluorescence intensity in both the Caco-2 mono-culture (an increase of $0.52 \pm 0.20 \times 10^{-2}$ relative fluorescence units / cell, $p<0.01$ ) and Caco-2 / 3 T3 co-culture model (an increase of $0.69 \pm 0.38 \times 10^{-2}$ relative fluorescence units / cell, $p<0.05$ ), indicating both models demonstrated verapamil-sensitive ABCB1 activity.

In the control condition (no verapamil), the normalised single cell calcein fluorescence intensity in Caco-2 cells within the mono-culture model was $0.96 \pm 0.11 \times 10^{-2}$ relative fluorescence units / cell, whilst in the 3D co-culture model was $2.29 \pm 0.31 \times 10^{-2}$ relative fluorescence units / cell. These findings indicate significantly lower $(p<0.05)$ ABCB1 activity (i.e. higher intracellular accumulation) in the Caco-2 / 3T3 3D co-culture model compared to the Caco-2 mono-culture model.
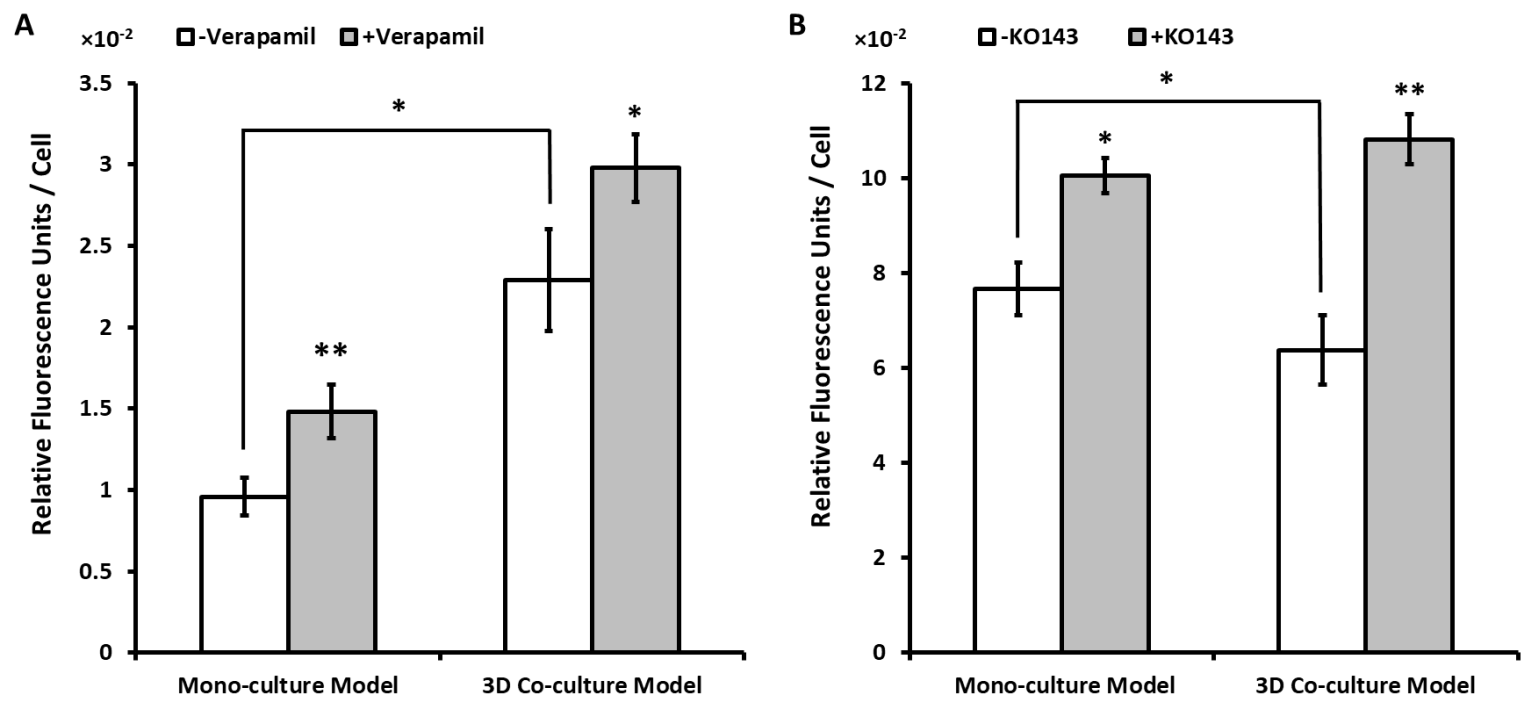
Figure 6 The activities of the ABCB1 and ABCG2 transport proteins. A) The effect of the ABCB1 inhibitor verapamil on normalised intracellular calcein fluorescence intensity (Relative Fluorescence Units / Cell) in Caco-2 mono-culture and the Caco-2 / 3 T3 co-culture model. B) The effect of the ABCG2 inhibitor Ko143 on normalised intracellular Hoechst 33342 fluorescence intensity (Relative Fluorescence Units / Cell) in Caco-2 mono-culture and the Caco-2 / 3 T3 co-culture model. Results are mean $\pm \mathrm{SD}$ of three independent experiments, with 3 replicates in each experiment $* p<0.05,{ }^{* *} p$ $<0.01$.

KO143-sensitive ABCG2 efflux activity was measured in both the Caco-2 mono-culture and

Caco-2 / 3T3 3D co-culture models, Figure 6 B. Treatment with the ABCG2 inhibitor KO143 $(10 \mu \mathrm{M})$, resulted in a significant increase in the normalised intracellular Hoechst 33342 fluorescence in both the Caco-2 mono-culture (an increase of $2.39 \pm 0.67 \times 10^{-2}$ relative fluorescence units / cell, $p<0.05$ ) and 3D co-culture model (an increase of $4.44 \pm 0.90 \times 10^{-2}$ relative fluorescence units / cell, $p<0.01$ ), indicating both models demonstrated KO143sensitive ABCG2 activity.

In the control condition (no KO143), the normalised Hoechst 33342 fluorescence intensity in Caco-2 cells within the mono-culture model was $7.66 \pm 0.56 \times 10^{-2}$ relative fluorescence units / cell, whilst in the $3 \mathrm{D}$ co-culture model was $6.37 \pm 0.73 \times 10^{-2}$ relative fluorescence units / cell. These findings indicate significantly higher $(p<0.05)$ ABCG2 activity (i.e. lower intracellular accumulation) in the 3D co-culture model compared to the Caco-2 mono-culture model.

Lower expression of $\mathrm{ABCB} 1$ and higher expression of ABCG2 suggests that the Caco-2 / 3T3 co-culture model is physiologically closer to human small intestine. 


\section{Drug Permeability}

A series of investigations were undertaken to measure the apparent permeability of model drugs with reported low (enalaprilat, lisinopril, lucifer yellow), moderate (atenolol, furosemide, hydrohlorothiazide) and high (antipyrine, propranolol, ketoprofen) apparent permeabilities. In addition, the apparent permeability of model drugs (digoxin, verapamil and quinidine) that are subjected to transported-mediated efflux (Eff) was measured. Importantly, different mechanisms are responsible for the absorptive transport of these drugs, namely passive transcellular, PT, transport (lisinopril, antipyrine, propranolol, ketoprofen, digoxin, verapamil and quinidine) and passive paracellular, PP, transport (enalaprilat, lucifer yellow, atenolol, furosemide and hydrohlorothiazide) (Skolnik et al. 2010), as shown in Table 1 In this work the $\mathrm{P}_{\text {app }}$ of the 12 model drugs, listed in Table 1, was compared to the corresponding fraction of the dose absorbed (Fa \%) in human studies (Skolnik et al. 2010; Artursson and Karlsson 1991; Levin 1980). In the high permeability group, $\mathrm{P}_{\text {app }}$ values in the Caco-2 / 3 T3 co-culture model are lower than those in the Caco-2 mono-culture model, whilst $\mathrm{P}_{\mathrm{app}}$ values are higher in the co-culture model in moderate and low permeability

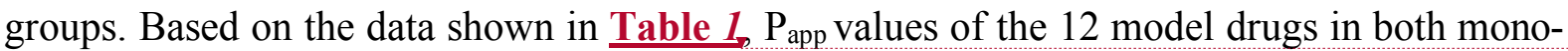
culture and co-culture cell models were compared with the respective human $\mathrm{Fa} \%$ values (Figure 7). The correlation coefficient $\left(\mathrm{R}^{2}\right)$ of data obtained from the mono-culture cell model compared to human $\mathrm{Fa} \%$ is 0.83 , whilst the $\mathrm{R}^{2}$ of data obtained from the $3 \mathrm{D}$ coculture model is higher, 0.87 , showing a slightly better correlation between human drug absorption and drug permeability measured in the co-culture cell model. 
Table 1 Transport and absorption characteristics of high, moderate and low permeability drugs in Caco-2 cell mono-culture and Caco-2 / 3T3 co-culture models, and fraction of dose absorbed (Fa \%) in human.

\begin{tabular}{|c|c|c|c|c|c|}
\hline \multirow[b]{2}{*}{ Permeability } & \multirow[b]{2}{*}{ Drugs } & \multirow[b]{2}{*}{$\begin{array}{c}\text { Primary } \\
\text { transport } \\
\text { mechanisms }^{\mathrm{a}}\end{array}$} & \multicolumn{2}{|c|}{$\mathrm{P}_{\text {app }}\left(\times 10^{-6} \mathrm{~cm} / \mathrm{s}\right)$} & \multirow[b]{2}{*}{$\mathrm{Fa}(\%)^{\mathrm{b}}$} \\
\hline & & & $\begin{array}{l}\text { Caco-2 } \\
\text { mono- } \\
\text { culture } \\
\text { model } \\
\end{array}$ & $\begin{array}{l}\text { Caco-2 / } \\
3 \text { T3 co- } \\
\text { culture } \\
\text { model } \\
\end{array}$ & \\
\hline \multirow{3}{*}{ Low } & Enalaprilat & PP & $0.62 \pm 0.08$ & $1.09 \pm 0.02$ & 10 \\
\hline & Lisinopril & PT & $0.85 \pm 0.09$ & $1.49 \pm 0.20$ & 28 \\
\hline & Lucifer Yellow & PP & $0.06 \pm 0.01$ & $0.18 \pm 0.02$ & NA \\
\hline \multirow{3}{*}{ Moderate } & Atenolol & PP & $1.51 \pm 0.06$ & $3.17 \pm 0.34$ & 50 \\
\hline & Furosemide & $\begin{array}{c}\text { PP, Eff } \\
\text { (ABCG2, } \\
\text { ABCC2) } \\
\end{array}$ & $3.49 \pm 0.33$ & $5.24 \pm 0.49$ & 60 \\
\hline & Hydrochlorothiazide & PP & $2.56 \pm 0.24$ & $4.70 \pm 0.13$ & 67 \\
\hline \multirow{3}{*}{ High } & Antipyrine & PT & $28.10 \pm 3.02$ & $17.00 \pm 1.81$ & 100 \\
\hline & Propranolol & PT & $17.50 \pm 1.01$ & $11.10 \pm 0.74$ & 90 \\
\hline & Ketoprofen & PT & $12.7 \pm 3.85$ & $11.80 \pm 3.70$ & 100 \\
\hline \multirow{3}{*}{$\begin{array}{c}\text { Efflux } \\
\text { substrates }\end{array}$} & Digoxin & $\begin{array}{c}\text { PT, Eff } \\
\text { (ABCB1) }\end{array}$ & $1.27 \pm 0.03$ & $2.78 \pm 0.06$ & 81 \\
\hline & Verapamil & $\begin{array}{c}\text { PT, Eff, } \\
\text { (ABCB1) }\end{array}$ & $12.70 \pm 2.72$ & $19.30 \pm 3.80$ & 95 \\
\hline & Quinidine & $\begin{array}{l}\text { PT, Eff, } \\
\text { (ABCB1) }\end{array}$ & $11.30 \pm 3.10$ & $10.30 \pm 2.76$ & 81 \\
\hline
\end{tabular}

aPrimary transport mechanism are cited from literature (Skolnik, Lin et al. 2010, Ebner, Ishiguro et al. 2015). PT: passive transcellular; PP: passive paracellular; Eff: efflux transporter substrate.

${ }^{\mathrm{b}}$ The human Fa \% values are cited from literature (Skolnik et al. 2010; Artursson and Karlsson 1991; Levin 1980). 
Caco-2 Mono-culture Model

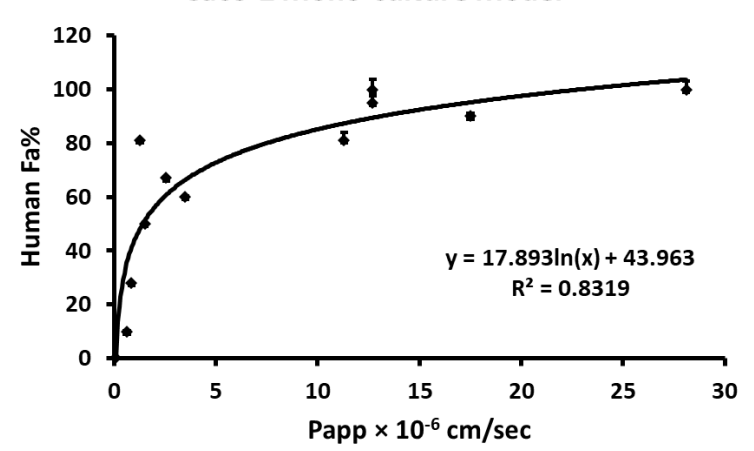

B

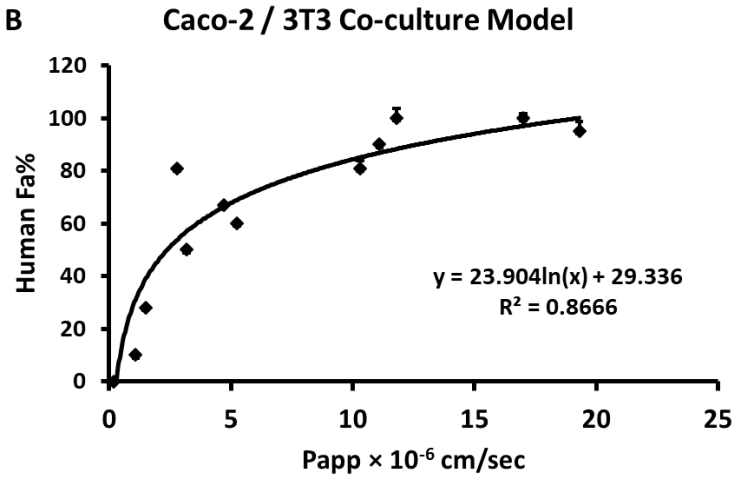

Figure 7 The logarithmic correlation between absorptive $\mathrm{P}_{\text {app }}$ values and human $\mathrm{Fa} \%$ in Caco-2 mono-culture cell model (A), correlation coefficient $\mathrm{R}^{2}=0.83$; and in Caco-2 / 3T3 3D co-culture cell model (B), correlation coefficient $\mathrm{R}^{2}=0.87$. Results are mean $\pm \mathrm{SD}$ of two independent experiments, with 2 replicates in each experiment.

\section{Discussion}

The Caco-2 cell mono-culture model is the model most commonly used for analysing drug permeability and human oral drug absorption (Hidalgo, Raub, and Borchardt 1989b; Artursson and Karlsson 1991, Samy et al. 2019). However, it has several limitations: it only simulates the epithelial layer of the human small intestine in vivo; the intercellular tight junctions are overly restrictive and the paracellular permeability is low than in vivo and the expression levels of functional transporter proteins differ from in vivo. Consequently, these shortcomings of the Caco-2 cell mono-culture model limit its usage in further experimental and clinical research (DiMarco et al. 2017b). In order to address these limitations, Caco-2 cell mono-cultures were combined with $3 \mathrm{~T} 3$ cells incorporated in type I collagen matrix to develop a more comprehensive and multi-dimensional cell model. This model not only represents the epithelial layer but also the subepithelial fibroblasts and extracellular matrix. 
We firstly examined the morphology and viability of the Caco-2 / 3T3 3D model using fluorescent dyes to stain both cell layers. Prior to co-culturing, Caco-2 cells and 3T3 cells were independently stained. The $3 \mathrm{~T} 3$ cells incorporated into the collagen gel were allowed to grow for a period of 2 days, then the stained Caco-2 cells were seeded onto the top of the gel and fluorescent imaging was carried out. Fluorescent image analysis revealed the Caco-2 cells attached well to the collagen layer and good viability of Caco-2 cells and 3T3 cells within the collagen gel. Furthermore, the fluorescent cross-sectional view in Figure 1 offered an intuitive understanding of the new Caco-2 / 3T3 3D model.

After 21 days, TEM imaging was used to investigate the differentiation of the model, focusing on evaluating the morphology of the Caco-2 cells. The latter demonstrated characteristics of differentiation in both mono-culture and 3D cell models, namely regular, well-developed microvilli, tight junctions, and desmosomes. These observations were consistent with previous studies of Caco-2 cell morphology (Hidalgo, Raub, and Borchardt $1989 \mathrm{~b}$ ) and indicated that the Caco-2 cells within the co-culture model resemble mature human enterocytes. In addition, close association between Caco-2 cells and the 3T3 cellcontaining collagen matrix was clearly observed (Figure $2 \mathrm{C}$ ).

In the Caco-2 / 3T3 co-culture model, the 3 T3 cells and collagen gel layer influenced the characteristics of the Caco- 2 cell mono-culture growing above it. In the $3 \mathrm{D}$ co-culture model the TEER of the Caco-2 cells was less than the TEER of Caco-2 mono-culture model whilst the permeability of the paracellular marker Lucifer yellow was greater. These observations demonstrated that the subepithelial layer consisting of 3T3 cells and collagen gel matrix modulated the permeability characteristics of Caco-2 cell tight junctions in the co-culture model, which was consistent with the finding that fibroblasts could influence epithelial cell function, including proliferation, migration, transepithelial resistance and secretory responses (Powell et al. 1999a; 1999b). It has been reported that, in vivo, the TEER of human small 
intestine is $69 \Omega \cdot \mathrm{cm}^{2}$ (Rubas et al. 1993). The findings of the current studies show that combining a Caco-2 cell mono-culture with a $3 \mathrm{~T} 3$ cell-containing matrix into a co-culture model significantly reduced the TEER of the Caco-2 cell mono-culture, making the coculture model more representative of the small intestine in vivo (Srinivasan et al. 2015).

Consistent with a reduced TEER in the Caco-2 / 3T3 3D co-culture model, the apparent permeability of Lucifer yellow was increased compared to that in Caco-2 cell mono-cultures, indicating that a functional change in paracellular permeability is associated with a change in TEER. Therefore, the current studies have demonstrated that the novel Caco-2 / 3T3 coculture model generated could alleviate some limitations observed in the conventional Caco-2 mono-culture model. These findings were consistent with previous work by Li et al. who also observed decreased TEER and increased fluorescein permeability in their cocultured model, which was considered more physiologically relevant (Li et al. 2013).

Another limitation of the Caco-2 mono-culture model we tried to overcome is the different expression profile of transporters, such as $\mathrm{ABCB} 1$ and $\mathrm{ABCG} 2$, in Caco-2 cells compared to small intestinal epithelial cells. It has been demonstrated that the level of ABCB1 expression in the Caco-2 mono-culture model is much higher than that in human small intestine (Anderle et al. 1998). Thus, there is a risk that predicted permeability of some compounds may be underestimated in the conventional mono-culture Caco-2 model. In the novel Caco-2 / 3T3 cell co-culture model, ABCB1 efflux activity was significantly lower than that observed in Caco-2 cell mono-cultures, as demonstrated by a $139.0 \%$ increase in intracellular accumulation of ABCB1 substrate (Figure 6, A, white bars).

The level of expression of ABCG2 in Caco-2 cells is reported to be lower than in the human small intestine (Maubon et al. 2007). In the current study, there was a small, although significant, $16.8 \%$ decrease in intracellular accumulation of ABCG2 substrate in the Caco-2 / 3T3 co-culture model compared to Caco-2 cell mono-cultures, (Figure 6, B, white bars), 
suggesting higher ABCG2 activity in the Caco-2 / 3T3 co-culture model, although this change in ABCG2 activity is substantially less than that observed for ABCB1.

To further evaluate the novel Caco-2 / 3T3 co-culture model, drug permeability in the model was compared to permeability in the mono-culture model. The $\mathrm{P}_{\mathrm{app}}$ values of high permeability compounds in the Caco-2 / 3T3 co-culture model were lower than those observed in the mono-culture cell model, whilst the $\mathrm{P}_{\text {app }}$ values were higher in the Caco-2 / 3T3 co-culture model for moderate and low permeability compounds. The co-culture model provided a better correlation between experimental permeability and human in vivo Fa \%. For all high permeability compounds (that were not subjected to efflux), the mechanism of absorptive transport was passive transcellular diffusion, and the 3T3 cell-collagen layer likely impedes the permeability of these compounds (Li et al. 2013). In contrast, the transport mechanism of most moderate or low permeability compounds tested was paracellular. As the 3 T3 cells-collagen layer modified the characteristics of Caco- 2 cells in the co-culture model (i.e. reduced TEER), a higher absorptive permeability for these types of compounds was observed than that in the traditional Caco-2 mono-culture model.

\section{Conclusion}

A new small intestinal cell model has been prepared by growing an epithelial Caco-2 monoculture on top of a 3T3 cell-impregnated collagen gel matrix. This 3D Caco-2 / 3T3 coculture model displayed several improvements over the traditional Caco-2 mono-culture model, including increased hydrolytic enzyme activity, reduced TEER, more appropriate expression level of $\mathrm{ABCB} 1$, and improved correlation between experimental drug permeability and in vivo drug absorption, which indicated that the novel cell model better represents the in vivo human intestine than does the mono-culture model. 
The Caco-2 / 3T3 3D co-culture model will be employed to study the permeability characteristics of a larger, and more physicochemically diverse, range of drugs, nutrients and dietary and environmental toxins and carcinogens in a system that more closely represents human small intestine. Future studies will focus on increasing the physiological complexity of this model by incorporating more cell types, such as goblet cells and immune cells, in order to simulate more features of human small intestine.

\section{Acknowledgement}

The authors would like to acknowledge Dr Aleksandr Mironov for assistance with transmission electron microscopic imaging and Mrs Rehana Sung for assistance with HPLC. We thank the School of Physics and Astronomy, University of Manchester, for an overseas research studentship to JZ. This work also benefited from the grant support from EPSRC (EP/F062966/1) and Innovate UK (KTP009043).

\section{References}

Al-Ali A A A, Steffansen B, Holm R and Nielsen C U. 2018. Nonionic surfactants increase digoxin absorption in Caco-2 and MDCKII MDR1 cells: Impact on P-glycoprotein inhibition, barrier function, and repeated cellular exposure. International journal of pharmaceutics 551: 270-280.

Allen J D, Van Loevezijn A, Lakhai J M, Van Der Valk M, Van Tellingen O, Reid G, Schellens J H, Koomen G J and Schinkel A H. 2002. Potent and Specific Inhibition of the Breast Cancer Resistance Protein Multidrug Transporter in Vitro and in Mouse Intestine by a Novel Analogue of Fumitremorgin C 1. Molecular cancer therapeutics 1: 417-425.

Anderle P, Niederer E, Rubas W, Hilgendorf C, Spahn-Langguth H, Wunderli-Allenspach H, Merkle H P and Langguth P. 1998. P-Glycoprotein (P-gp) mediated efflux in Caco-2 cell monolayers: the influence of culturing conditions and drug exposure on P-gp expression levels. Journal of pharmaceutical sciences 87: 757-762.

Antunes F, Andrade F, Araújo F, Ferreira D and Sarmento B. 2013. Establishment of a triple co-culture in vitro cell models to study intestinal absorption of peptide drugs. European Journal of Pharmaceutics and Biopharmaceutics 83: 427-435. 
Artursson P and Karlsson J. 1991. Correlation between oral drug absorption in humans and apparent drug permeability coefficients in human intestinal epithelial (Caco-2) cells. Biochemical and biophysical research communications 175: 880-885.

Artursson P, Ungell A L and Löfroth J E. 1993. Selective paracellular permeability in two models of intestinal absorption: cultured monolayers of human intestinal epithelial cells and rat intestinal segments. Pharmaceutical research 10: 1123-1129.

Balda M S, Fallon M B, Van Itallie C M and Anderson J M. 1992. Structure, regulation, and pathophysiology of tight junctions in the gastrointestinal tract. The Yale journal of biology and medicine 65: 725-740.

Basson M D, Turowski G A, Rashid Z, Hong F and Madri J A. 1996. Regulation of human colonic cell line proliferation and phenotype by sodium butyrate. Digestive diseases and sciences 41: 1986-1993.

Bhagwate S and Gaikwad N J. 2013. Stability indicating HPLC method for the determination of hydrochlorothiazide in pharmaceutical dosage form. Journal of Applied Pharmaceutical Science 3: 88-92.

Bradford M M. 1976. A rapid and sensitive method for the quantitation of microgram quantities of protein utilizing the principle of protein-dye binding. Analytical biochemistry 72: 248-254.

Charde M and Welankiwar A S. 2014. Development of validated RP-HPLC method for the simultaneous estimation of atenolol and chlorthalidone in combine tablet dosage form'. International journal of advances in pharmaceutics 3: 06-18.

DiMarco R L, Hunt D R, Dewi R E and Heilshorn S C. 2017 a. Improvement of paracellular transport in the Caco-2 drug screening model using protein-engineered substrates. Biomaterials 129: 152-162.

DiMarco R L, Hunt D R, Dewi R E and Heilshorn S C. 2017 b. Improvement of paracellular transport in the Caco-2 drug screening model using protein-engineered substrates. Biomaterials 129: 152-162.

Drygiannakis I, Valatas V, Sfakianaki O, Bourikas L, Manousou P, Kambas K, Ritis K, Kolios G and Kouroumalis E. 2013. Proinflammatory cytokines induce crosstalk between colonic epithelial cells and subepithelial myofibroblasts: implication in intestinal fibrosis. Journal of Crohn's and Colitis 7: 286-300.

Ebner T, Ishiguro N and Taub M E. 2015. The use of transporter probe drug cocktails for the assessment of transporter-based drug-drug interactions in a clinical setting - proposal of a four component transporter cocktail. Journal of pharmaceutical sciences 104: 3220-3228.

Estudante M, Morais J G, Soveral G and Benet L Z. 2013. Intestinal drug transporters: an overview. Advanced drug delivery reviews 65: 1340-1356.

Faralli A, Shekarforoush E, Ajalloueian F, Mendes A C and Chronakis I S. 2019. In vitro permeability enhancement of curcumin across Caco-2 cells monolayers using electrospun xanthan-chitosan nanofibers. Carbohydrate polymers 206: 38-47.

Felton J S, Jägerstad M, Knize M G, Skog K and Wakabayashi K. 2000. Contents in Foods, Beverages and Tobacco. Contents in Foods, Beverages and Tobacco, 31-71.

Flecknell P. 2002. Replacement, reduction, refinement. ALTEX-Alternatives to animal experimentation 19: 73-78. 
Furuya K, Sokabe M and Furuya S. 2005. Characteristics of subepithelial fibroblasts as a mechano-sensor in the intestine: cell-shape-dependent ATP release and P2Y1 signaling. J Cell Sci 118: 3289-3304.

Furuya S, Furuya K, Sokabe M, Hiroe T and Ozaki T. 2005. Characteristics of cultured subepithelial fibroblasts in the rat small intestine. II. Localization and functional analysis of endothelin receptors and cell-shape-independent gap junction permeability. Cell and tissue research 319: 103-119.

García-Rodríguez A, Vila L, Cortés C, Hernández A and Marcos R. 2018. Effects of differently shaped TiO 2 NPs (nanospheres, nanorods and nanowires) on the in vitro model (Caco-2/HT29) of the intestinal barrier. Particle and fibre toxicology 15: 33 .

Hidalgo I J, Raub T J and Borchardt R T. 1989 a. Characterization of the human colon carcinoma cell line (Caco-2) as a model system for intestinal epithelial permeability. Gastroenterology 96: 736-749.

Hidalgo I J, Raub T J and Borchardt R T. 1989 b. Characterization of the human colon carcinoma cell line (Caco-2) as a model system for intestinal epithelial permeability. Gastroenterology 96: 736-749..

Hymery N, Mounier J and Coton E. 2018. Effect of Penicillium roqueforti mycotoxins on Caco-2 cells: Acute and chronic exposure. Toxicology in Vitro 48: 188-194.

Isshiki M, Umezawa $\mathrm{K}$ and Tamura H. 2011. Coffee induces breast cancer resistance protein expression in Caco-2 cells. Biological and Pharmaceutical Bulletin 34: 1624-1627.

Kenny A J and Maroux S. 1982. Topology of microvillar membrance hydrolases of kidney and intestine. Physiological Reviews 62: 91-128.

Knize M G and Felton J S. 2005. Formation and Human Risk of Carcinogenic Heterocyclic Amines Formed from Natural Precursors in Meat. Nutrition Reviews 63: 158-165.

Korjamo T, Honkakoski P, Toppinen M R, Niva S, Reinisalo M, Palmgrén J J and Mönkkönen J. 2005. Absorption properties and P-glycoprotein activity of modified Caco-2 cell lines. European journal of pharmaceutical sciences 26: 266-279.

Kowapradit J, Opanasopit P, Ngawhirunpat T, Apirakaramwong A, Rojanarata T, Ruktanonchai U and Sajomsang W. 2010. In Vitro Permeability Enhancement in Intestinal Epithelial Cells (Caco-2) Monolayer of Water Soluble Quaternary Ammonium Chitosan Derivatives. AAPS PharmSciTech 11: 497-508.

Le Ferrec E, Chesne C, Artusson P, Brayden D, Fabre G, Gires P, Guillou F, Rousset M, Rubas W and Scarino M L. 2001. In vitro models of the intestinal barrier. Atla 29: 649-668.

Leonard F, Collnot E M and Lehr C M. 2010. A three-dimensional coculture of enterocytes, monocytes and dendritic cells to model inflamed intestinal mucosa in vitro. Molecular pharmaceutics 7: 2103-2119.

Levin V A. 1980. Relationship of octanol/water partition coefficient and molecular weight to rat brain capillary permeability. Journal of medicinal chemistry 23: 682-684.

Li N, Wang D, Sui Z, Qi X, Ji L, Wang X and Yang L. 2013. Development of an improved threedimensional in vitro intestinal mucosa model for drug absorption evaluation. Tissue Engineering Part $\mathrm{C}$ : Methods 19: 708-719. 
Maubon N, Le Vee M, Fossati L, Audry M, Le Ferrec E, Bolze S and Fardel O. 2007. Analysis of drug transporter expression in human intestinal Caco-2 cells by real-time PCR. Fundamental \& clinical pharmacology 21: 659-663.

Murakami T and Takano M. 2008. Intestinal efflux transporters and drug absorption. Expert opinion on drug metabolism \& toxicology 4: 923-939. Owens B M J and Simmons A. 2013. Intestinal stromal cells in mucosal immunity and homeostasis. Mucosal immunology 6: 224.

Pan F, Han L, Zhang Y, Yu Y and Liu J. 2015. Optimization of Caco-2 and HT29 co-culture in vitro cell models for permeability studies. International journal of food sciences and nutrition 66: 680-685.

Patil S, Kumar L, Kohli G and Bansal A. 2011. Validated HPLC method for concurrent determination of antipyrine, carbamazepine, furosemide and phenytoin and its application in assessment of drug permeability through Caco-2 cell monolayers. Scientia pharmaceutica 80: 89-100.

Penny, J. I., and F. C. Campbell. 1994. 'Active Transport of Benzo[a]Pyrene in Apical Membrane Vesicles from Normal Human Intestinal Epithelium'. Biochimica Et Biophysica Acta 1226: 232-36. https://doi.org/10.1016/0925-4439(94)90034-5.

Powell D W, Mifflin R C, Valentich J D, Crowe S E, Saada J I and West A B. 1999. Myofibroblasts. I. Paracrine cells important in health and disease. American Journal of Physiology-Cell Physiology 277: C1-C19.

Powell D W, Mifflin R C, Valentich J D, Crowe S E, Saada J I and West A B. 1999. Myofibroblasts. II. Intestinal subepithelial myofibroblasts. American Journal of Physiology-Cell Physiology 277: C183C201.

Rhayat L, Maresca M, Nicoletti C, Perrier J, Brinch K S, Christian S, Devillard E and Eckhardt E. 2019. Effect of Bacillus subtilis strains on intestinal barrier function and inflammatory response. Frontiers in immunology 10.

Rubas W, Cromwell M, Gadek T, Narindray D and Mrsny R. 1993. Structural elements which govern the resistance of intestinal tissues to compound transport. MRS Online Proceedings Library Archive 331: 179.

Samy K E, Levy E S, Phong K, Demaree B, Abate A R and Desai T A. 2019. Human Intestinal Spheroids Cultured Using Sacrificial Micromolding as a Model System for Studying Drug Transport. Scientific Reports 9: 1-12.

Schinkel A H and Jonker J W. 2012. Mammalian Drug Efflux Transporters of the ATP Binding Cassette (ABC) Family: An Overview. Advanced Drug Delivery Reviews 64: 138-153.

Schweinlin M, Wilhelm S, Schwedhelm I, Hansmann J, Rietscher R, Jurowich C, Walles H and Metzger M. 2016. Development of an advanced primary human in vitro model of the small intestine. Tissue Engineering Part C: Methods 22: 873-883.

Shen J and Wanwimolruk S. 1991. A simple and sensitive HPLC method for antipyrine in plasma. Journal of liquid chromatography 14: 2801-2808.

Skolnik S, Lin X, Wang J, Chen X H, He T and Zhang B. 2010. Towards prediction of in vivo intestinal absorption using a 96-well Caco-2 assay. Journal of pharmaceutical sciences 99: 3246-3265. 
Sobue K, Yamamoto N, Yoneda K, Hodgson M E, Yamashiro K, Tsuruoka N, Tsuda T, Katsuya H, Miura Y, Asai K and Kato T. 1999. Induction of blood-brain barrier properties in immortalized bovine brain endothelial cells by astrocytic factors. Neuroscience research 35: 155-164.

Srikanth M V, Ram B J, Sunil S A, Rao N S and Murthy K V. 2012. Development and validation of HPLC method for estimation of propranolol $\mathrm{HCl}$ in human plasma. JSIR 71: 120-123.

Srinivasan B, Kolli A R, Esch M B, Abaci H E, Shuler M L and Hickman J J. 2015. TEER measurement techniques for in vitro barrier model systems. Journal of laboratory automation 20: 107-126.

Srivastava M, Kohli K and Ali M. 2014. Stability Indicating RP-HPLC Method for Analysis of Ketoprofen in Bulk Drug and Eugenol Containing Nanoemulsion Gel (NEG) Formulation Using Response Surface Methodology. Current Pharmaceutical Analysis 10: 135-144.

Stockdale T P, Challinor V L, Lehmann R P, De Voss J J and Blanchfield J T. 2019. Caco-2 Monolayer Permeability and Stability of Chamaelirium luteum (False Unicorn) Open-Chain Steroidal Saponins. ACS Omega 4: 7658-7666.

Sultana N, Arayne M S, Siddiqui R and Naveed S. 2012. RP-HPLC method for the simultaneous determination of lisinopril and NSAIDs in API, pharmaceutical formulations and human serum. American Journal of Analytical Chemistry 3: 147-152.

Tajerzadeh H and Hamidi M. 2001. A simple HPLC method for quantitation of enalaprilat. Journal of pharmaceutical and biomedical analysis 24: 675-680.

Ulluwishewa D, Anderson R C, McNabb W C, Moughan P J, Wells J M and Roy N C. 2011. Regulation of tight junction permeability by intestinal bacteria and dietary components. The Journal of nutrition 141: 769-776.

Wu J J, Zhu Y F, Guo Z Z, Lou Y M, He S G, Guan Y, Zhu L J, Liu Z Q, Lu L L and Liu L. 2018. Aconitum alkaloids, the major components of Aconitum species, affect expression of multidrug resistance-associated protein 2 and breast cancer resistance protein by activating the Nrf2-mediated signalling pathway. Phytomedicine 44: 87-97.

Zhang L, Zheng Y, Chow M S and Zuo Z. 2004. Investigation of intestinal absorption and disposition of green tea catechins by Caco-2 monolayer model. International journal of pharmaceutics 287: 1-12.

Zucco F, Batto A, Bises G, Chambaz J, Chiusolo A, Consalvo R, Cross H, Negro G D, de Angelis I and Fabre G. 2005. An inter-laboratory study to evaluate the effects of medium composition on the differentiation and barrier function of Caco-2 cell lines. Altern Lab Anim 33: 603-618. 